\title{
Study on Optimization Path of Energy Consumption Structure of Container Terminal
}

\author{
Ruiyu $\mathrm{LI}^{\mathrm{a}}$, Haifeng FANG ${ }^{\mathrm{b}}$, Guodong $\mathrm{WANG}^{\mathrm{c}}$, Qingfang MA ${ }^{\mathrm{c}}$ \\ ${ }^{a}$ Environment Prevention and Energy Conservation Center, China Waterborne \\ Transport Research Institute, Beijing 100088, China \\ ${ }^{b}$ Putian Xiuyu Port Co., Ltd, Putian 351158, China \\ ${ }^{c}$ Professional Competence Center, Liaoning Port Group Co., Ltd, Dalian 116007, \\ China
}

\begin{abstract}
This study accounts current energy consumption of various types of equipments in Chinese container terminals through investigating typical terminals; compares and analyzes the clean energy application technologies from the perspectives of technical level, investment cost, and others; on this basis, construct the predictive model of energy consumption structure, and uses scenario analysis to carry out energy consumption predictions under each scenario and analyzes the effect of policy intervention, technological development and other factors. According to the predictive results, this study holds that in order to optimize energy structure of container terminal, container terminals should strongly promote the application of clean energy to port machinery instead of fuel on the basis of the industrial development and cost reduction of high-power and large-capacity power batteries; at the same time, strengthen policy encouragement and guidance are needed.
\end{abstract}

Keywords. Energy consumption structure, clean energy, carbon reduction, green transformations

\section{Introduction}

As an important energy-using system of the transportation industry, port industry takes on major responsibilities for energy conservation, carbon reduction and green transformation. According to the data of the International Energy Agency, China's energy consumption in transportation field in 2018 was 467 million tons of standard coal, accounting for $10.2 \%$ of the total energy consumption; Direct carbon emissions from transportation field are about 1 billion tons, accounting for about $10.7 \%$ of the total carbon emissions. In 2018, China's apparent oil consumption will reach 648 million tons, more than half of which will be used as transportation fuel. Diesel, gasoline, fuel oil and aviation kerosene will account for more than $90 \%$ of transportation energy. In the field of transportation energy consumption, waterway energy consumption accounts for about $23 \%[1]$.

Waterway transportation consists of port and shipping, among them, the port as an important link has become an important source of energy consumption and greenhouse

\footnotetext{
${ }^{1}$ Corresponding author: Ruiyu Li, Environment Prevention and Energy Conservation Center, China Waterborne Transport Research Institute, Beijing 100088, China; E-mail: liruiyu@wti.ac.cn.
} 
gas emissions. Low-carbon green development of the port will have a huge impact to the port and the city's economic development. According to the estimation of relevant research materials, at present, the total energy consumption of the port directly used for handling cargo production is about 2 million tons of standard coal per year, including about 600000 tons of diesel oil, equivalent to 874000 tons of standard coal, accounting for $43.7 \%$, and direct carbon emissions is 1.9 million tons [2]. The scale and carbon emissions of container terminals are relatively high among all types of ports in China, and the carbon emissions peak of container terminals plays an important role in carbon emissions peak of ports in China. Optimization energy consumption structure is an important way to promote carbon peak [3-5].

\section{Analysis of Current Energy Consumption Structure in Container Terminals}

\subsection{Production Process and Equipment of Container Terminal}

The production units of container terminal include cargo handling production, auxiliary production and ancillary production. The cargo handling process of container terminals is shown in Figure 1.

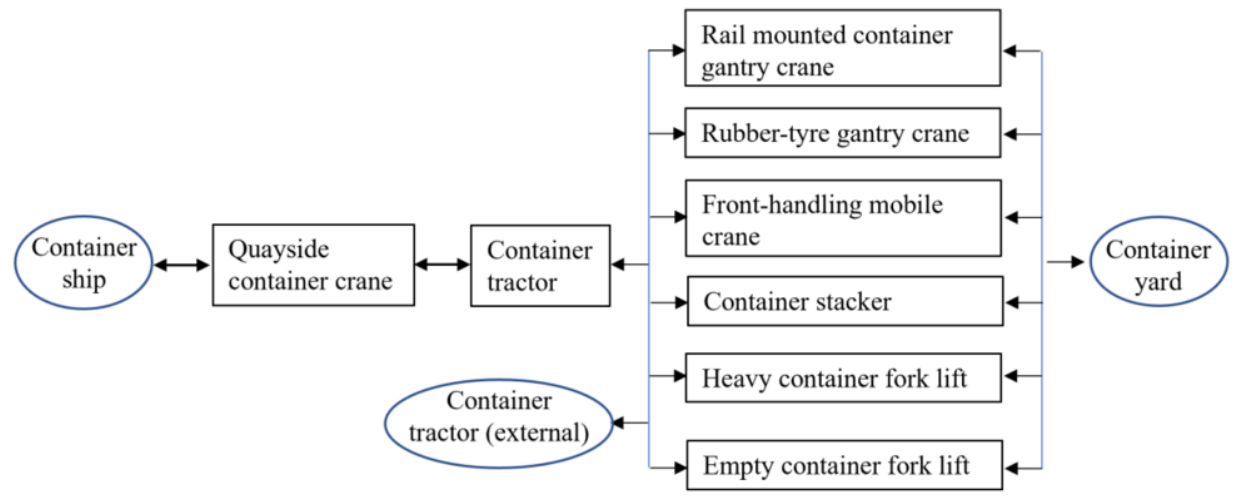

Figure 1. Cargo handling flow chart of container terminals.

Main handling machines of container terminal includes:

- Quayside container crane is crane for handling containers at the frontier of container terminals, hereinafter referred to as QC. QC works by electricity.

- Container tractor is special tractors for towing container trailers, including inner container tractors for transportation inside the container terminal and outer container tractors for transportation outside the port, hereinafter referred to as CT. CT runs on diesel oil or LNG.

- Rail mounted ganty crane is the gantry crane for handling containers in container yard that walks supported by steel wheels, hereinafter referred to as RMG. RMG works by electricity. 
- Rubber-tyre gantry crane is the gantry crane for handling containers in container yard that walks supported by tires, hereinafter referred to as RTG. RMG works by electricity or diesel oil.

- front-handling mobile crane is telescopic jib crane for handling containers in container yard that mounted on self-propelled tire chassis, hereinafter referred to as FHM. FHM works by diesel oil.

- Container stacker is machinery for stacking empty containers in container yard, hereinafter referred to as stacker. Stacker works by diesel oil or LNG.

- Heavy container fork lift is fork truck for handling and stacking heavy containers in container yard, hereinafter referred to as HFL. HFL works by diesel oil.

- Empty container fork lift is fork truck for handling and stacking empty containers in container yard, hereinafter referred to as EFL. EFL works by diesel oil or electricity.

The types of energy consumed by equipment of container terminal are shown in Figure 2.

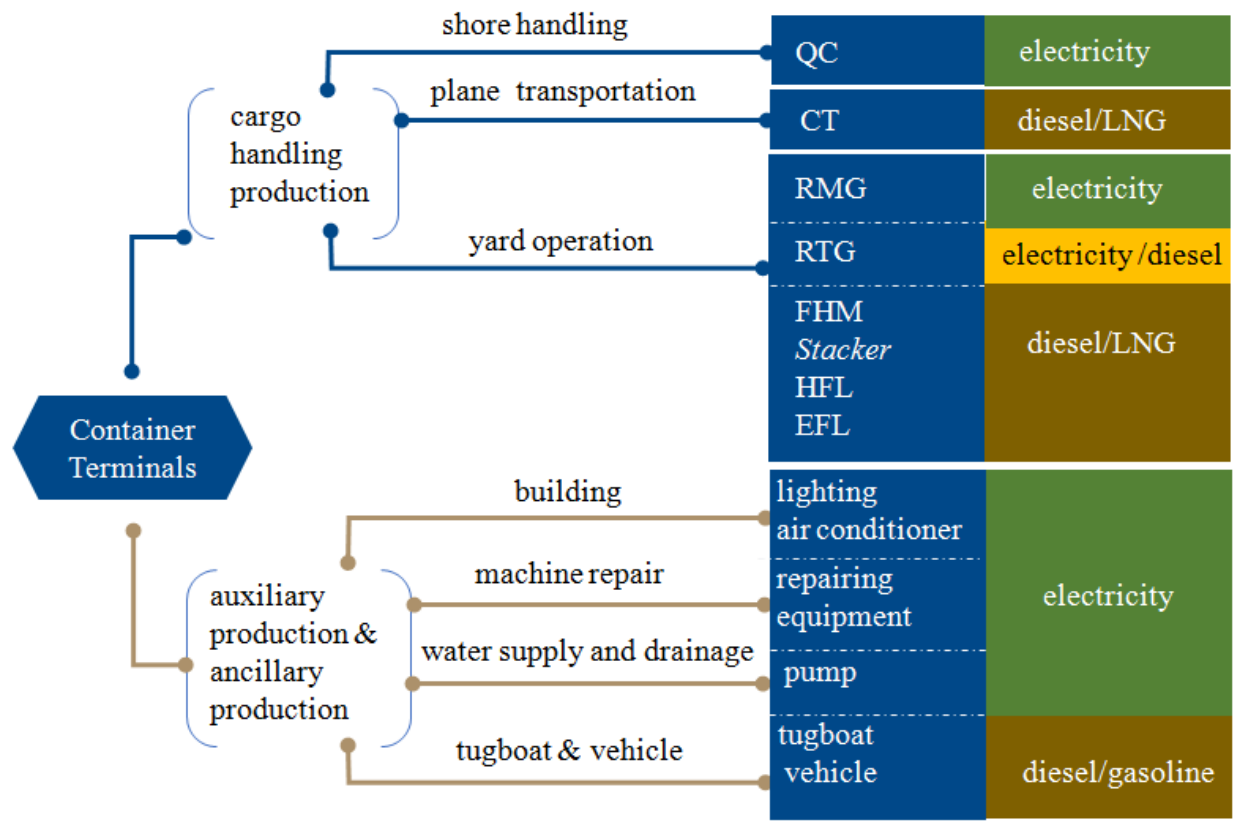

Figure 2. Types of energy consumed by equipment of container terminal.

\subsection{Current Situation of Energy Consumption Structure of China's Container Terminal}

Based on energy consumption of various types of equipment of China's typical container terminals, as well as the container terminals throughput and other production data published in the 2020 statistical yearbook, this study accounts energy consumption of various types of equipment of China's container terminals in 2020 as follows. 


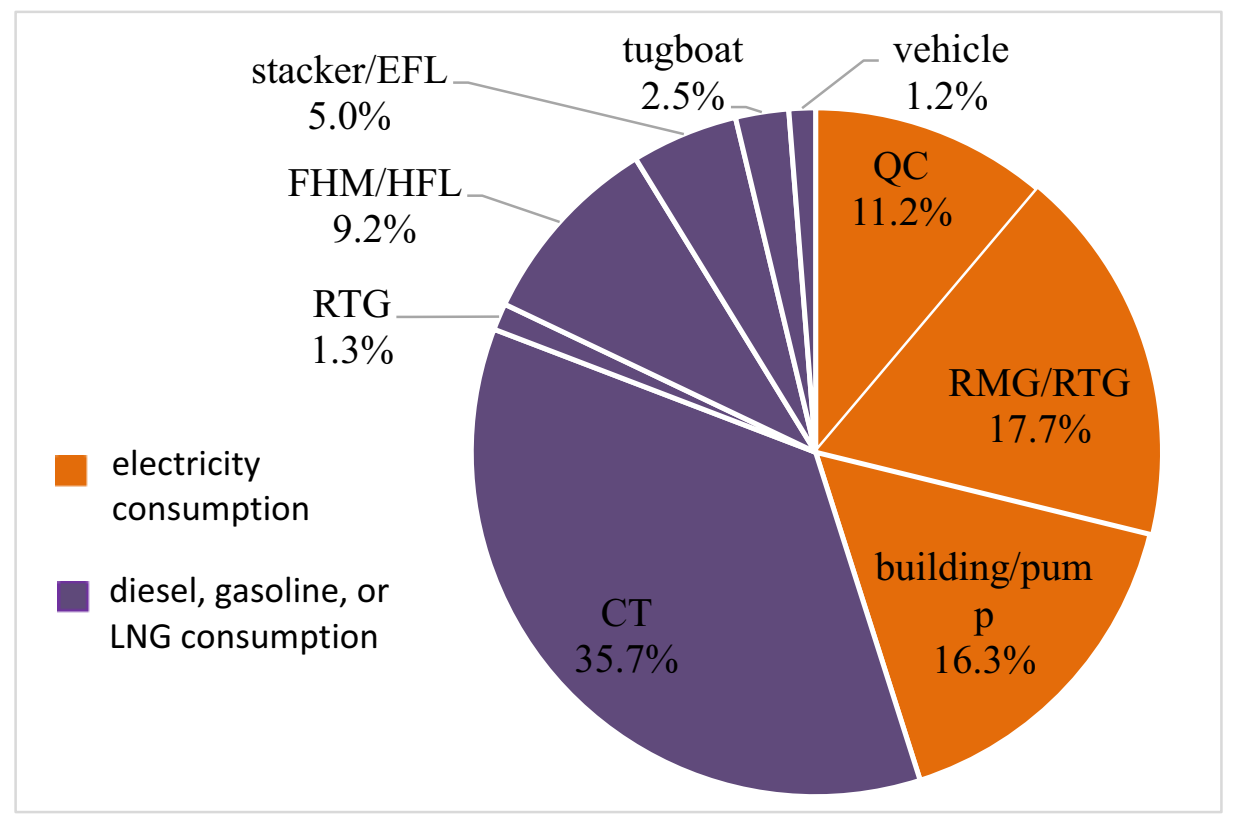

Figure 3. Current energy consumption structure of China's container terminals in 2020.

As can be seen from Figure 3 that in 2020, the total energy consumption of China's container terminals will be 872,000 tons of standard coal, of which the consumption of diesel, gasoline and LNG will be 479,000 tons of standard coal, accounting for about $55 \%$ of the total energy consumption, and the direct carbon emissions of China's container terminals will be about 1.033 million tons. In addition, it can be seen from Figure 3 that the consumption of diesel oil, gasoline and LNG of China's container terminals is more than that of electric power. In all of the equipment consuming diesel, gasoline or LNG, container tractor consumes most energy, and energy consumption accounts for about $35.7 \%$, and direct carbon emissions account for about $65.1 \%$.

\section{Optimization Measures of Energy Consumption Structure of Container Terminal}

Optimization measures of energy consumption structure of container terminal include promoting the application of clean energy such as electric energy and hydrogen energy instead of oil/gas in port machineries. This paper analyzes the clean energy application technologies of different types of port machineries and vehicles in container terminals as follows [6]:

\subsection{Container Tractor (Lithium-Powered Batteries)}

- Status of technology application: Unmanned container tractors are used in Tianjin Port and Xiamen Port Harun Wharf; manned electric container tractors are used in ports such as Wuhan Yangluo Port. 
- $\quad$ Status of technology development: The maximum speed of electric container tractors is adjustable and the output torque is stable, which meets the basic technical parameters of container trailers. Battery life and charging time are difficult to meet the requirements of $24 \mathrm{~h}$ continuous operation, affecting the efficiency of terminal operations.

- Cost-effectiveness: According to the 10-year life cycle, it is estimated that the annual operating cost of electric container tractors is about $10 \%$ higher than that of diesel-driven ones.

\subsection{Container Tractor (Hydrogen Fuel Cells)}

- Status of technology application: In 2019, three hydrogen energy container tractors were officially put into live demonstration operation in Qingdao Port, putting China's first new energy (hydrogen fuel + pure electric energy) heavy trucks into use, known as the first mass use of energy container tractors in the domestic port industry.

- Status of technology development: The main performance indicators of container tractors driven by hydrogen fuel, such as power and endurance meet the production needs, but the hydrogen fuel supply conditions are not perfect.

- Cost-effectiveness: According to the 10-year life cycle, it is estimated that the annual operating cost of container tractors driven by hydrogen energy is about three times higher than that of diesel-driven ones.

\subsection{RTG (Mains +Lithium Batteries / External Power Supplies)}

- Status of technology application: Domestic container terminal RTG's loading and unloading operations have been driven by mains power, but most terminal RTG transfers are still driven by small diesel engines.

- Status of technology development: The large-capacity lithium battery can basically meet the energy demand of wheeled crane transfers.

- Cost-effectiveness: As energy storage technology develops, the cost of chemical fuel cells such as lithium batteries has gradually reduced.

\subsection{FHM/HFL (Lithium Batteries)}

- Status of technology application: Electric container reach stackers have been tested or put into use in Ningbo Port, Xuzhou Port and other ports.

- Status of technology development: Electric container reach stackers vary greatly in load and have high requirements for battery power density.

- Cost-effectiveness: The purchase cost of an electric container reach stacker is much higher than that of a diesel-driven one, but its fuel cost is lower.

\subsection{Stacker/EFL (Lithium Batteries) [7]}

- Status of technology application: Electric empty container handlers have been applied in Shantou CMPort Container Company and Xiamen Port Haitian Terminal.

- Status of technology development: The response speed of electric empty container handlers on the move is faster than that of internal combustion engines. The lifting speed is more uniform with unobvious ups and downs. Thus drivers can quickly adapt to and get familiar with the operation. In addition, the noise is significantly smaller 
than that of internal combustion engines. But the battery operation capability needs to be further improved.

- Cost-effectiveness: Compared with diesel-driven ones, the cost of electric empty container handlers is higher. But the investment cost can be recovered within about 3 years.

\section{Scenario Analysis of Optimization Energy Consumption Structure of Container Terminals}

\subsection{Set Scenarios of Energy Consumption Structure of Container Terminals}

This paper takes the clean energy technology application scale of various port machines and vehicles as the influencing factors, and the application scale is influenced by policy intervention, technological development and so on. According to the clean energy technology application scale of various port machines and vehicles, this study takes 2030 as the target year and set three scenarios as follows.

\subsubsection{Baseline Scenario}

The baseline scenario refers to under a background of no new policies and the development of technologies such as clean energy is slow, the clean energy technology application scale of various port machines and vehicles are not widespread. Under this scenario, the port enterprises phase out fossil fuel equipment in accordance with their ages and working performance by convention, and few clean energy equipment are selected.

\subsubsection{Policy Intervention Scenario}

Policy intervention scenario means that the government adopts policy constraints, tax incentives, pilot demonstrations and other measures to encourage and guide port enterprises to carry out optimization measures of energy consumption structure, and under which the clean energy technology application scale of various port machines and vehicles will progress. Under this scenario, port companies invest more money in optimization energy consumption structure, accelerate the phase-out of fossil fuel equipments, and more clean energy or low-carbon equipments are selected. In addition, port enterprises are increasingly adopting information technology and intelligent technology to improve the production efficiency of port equipments.

\subsubsection{Technological Breakthrough Scenario}

The technological breakthrough scenario refers to under a background of clean energy application technology breakthrough, the clean energy technology of port mobile machinery and vehicles develop rapidly. Port enterprises accelerate the adoption of clean energy technologies and the selection of high-efficient low-carbon products for mobile machinery and vehicles on a large scale. And, with the rapid development of intelligent and information technology, the container terminal intelligence has increased significantly.

Based on aforementioned information, the paper sets out proportion of the clean energy technology application scale of various port machines and vehicles respectively 
in table 1.

Table 1. Proportion of clean energy technology application scale of various port machines and vehicles under three scenarios.

\begin{tabular}{llll}
\hline & $\begin{array}{l}\text { Baseline } \\
\text { scenario }\end{array}$ & $\begin{array}{l}\text { Policy intervention } \\
\text { scenario }\end{array}$ & $\begin{array}{l}\text { Technological breakthrough } \\
\text { scenario }\end{array}$ \\
\hline CT & $40 \%$ & $60 \%$ & $90 \%$ \\
RTG & $30 \%$ & $50 \%$ & $70 \%$ \\
FHM/HFL & $30 \%$ & $50 \%$ & $70 \%$ \\
Stacker/EFL & $40 \%$ & $60 \%$ & $90 \%$ \\
Tugboat & $20 \%$ & $40 \%$ & $60 \%$ \\
Port vehicles & $40 \%$ & $60 \%$ & $90 \%$ \\
\hline
\end{tabular}

\subsection{Forecast Energy Consumption Structure of Container Terminal}

This paper forecast the energy consumption structure in China's container terminals under three scenarios as follows [8-9].

\subsubsection{Baseline Scenario}

The energy consumption structure in China's container terminal in 2030 under baseline scenario is forecast as follow.

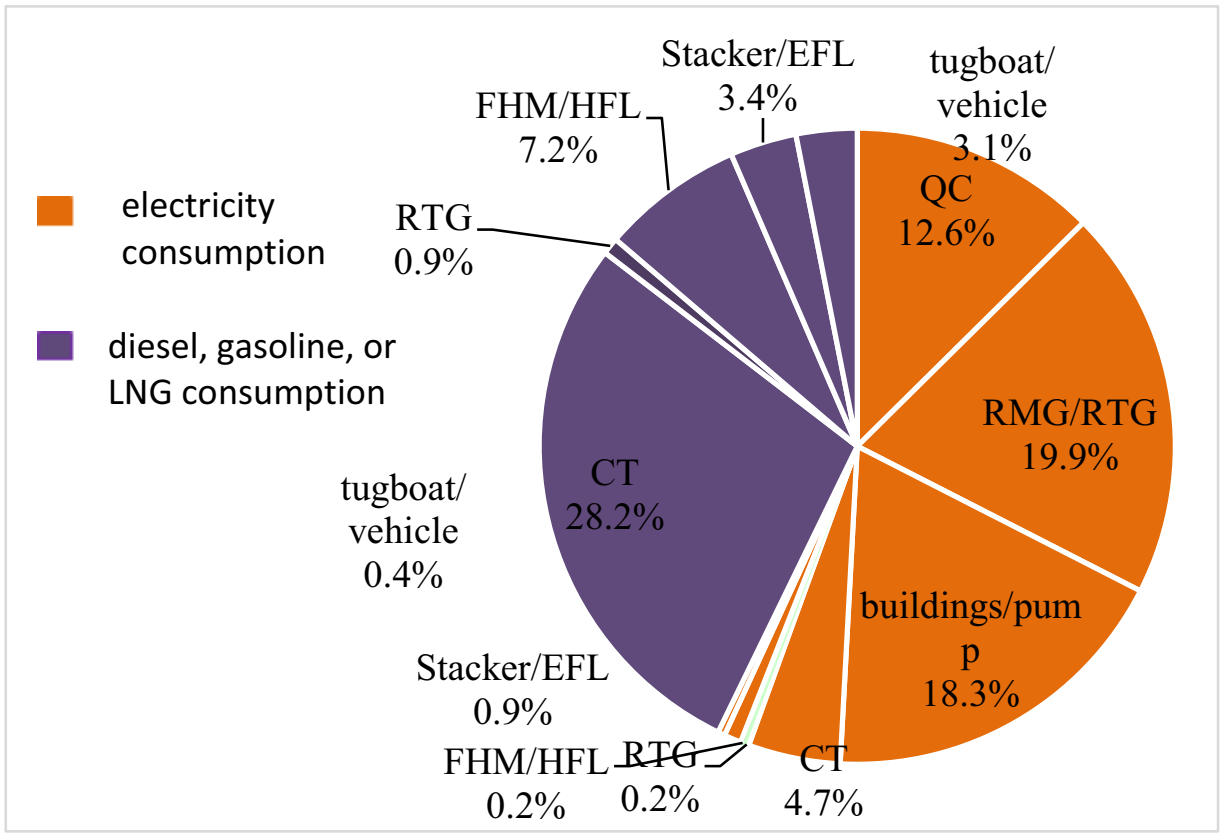

Figure 4. Forecast energy consumption structure in China's container terminal under baseline scenario.

As can be seen from Figure 4 that, in 2030 under the baseline scenario:

- Consumption of diesel, gasoline and LNG will account for about $42.8 \%$ of the total energy consumption, which is $12.2 \%$ lower than now. In addition, it can be seen from Figure 4 that the consumption of diesel oil, gasoline and LNG of China's container 
terminals is less than that of electric power. In all of the equipment consuming diesel, gasoline or LNG, container tractor consumes most energy, and energy consumption accounts for about $28.2 \%$.

- The direct carbon emissions of China's container terminals per throughput will be about $31 \%$ lower.

\subsubsection{Policy Intervention Scenario}

The energy consumption structure in China's container terminal in 2030 under policy intervention scenario is forecast as follow.

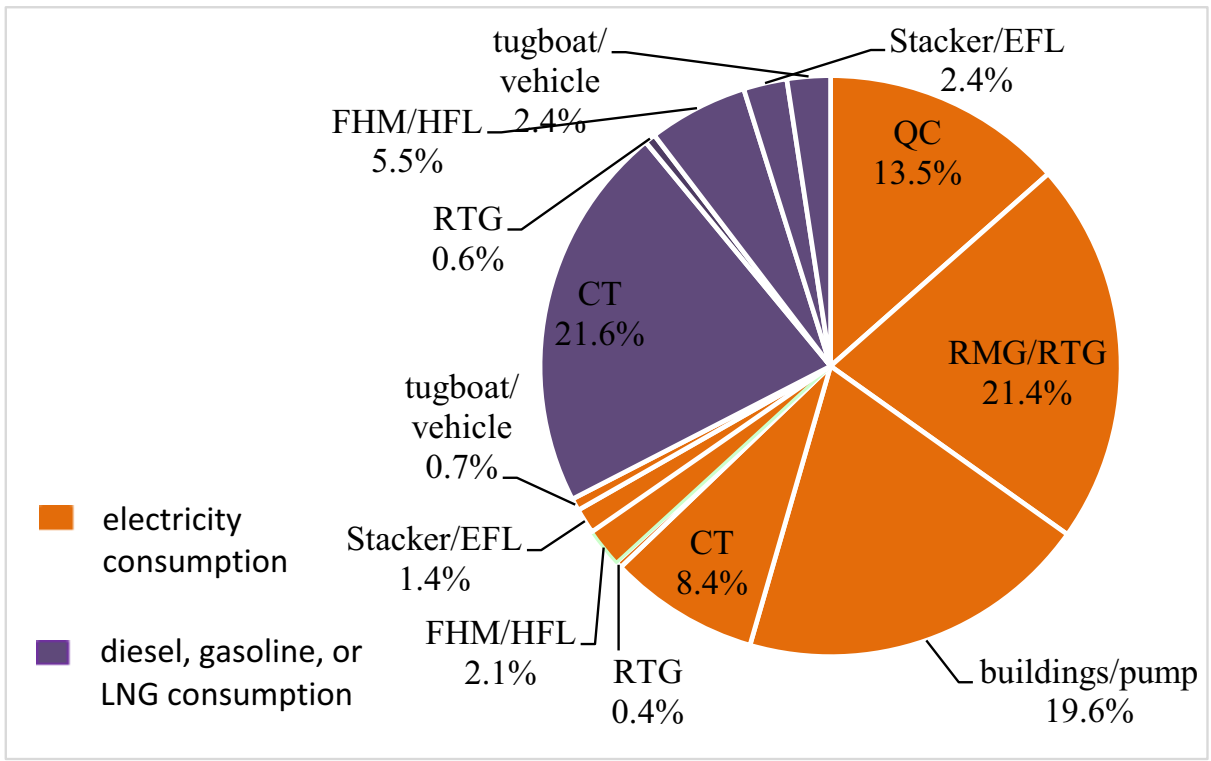

Figure 5. Forecast energy consumption structure in China's container terminal under policy intervention scenario.

As can be seen from Figure 5 that, in 2030 under the policy intervention scenario:

- Consumption of diesel, gasoline and LNG will account for about $32.6 \%$ of the total energy consumption, which is $22.4 \%$ lower than now. In addition, it can be seen from Figure 5 that the consumption of diesel oil, gasoline and LNG of China's container terminals is less than that of electric power. In all of the equipment consuming diesel, gasoline or LNG, container tractor consumes most energy, and energy consumption accounts for about $21.6 \%$.

- The direct carbon emissions of China's container terminals per throughput will be about $51 \%$ lower.

\subsubsection{Technological Breakthrough Scenario}

The energy consumption structure in China's container terminal in 2030 under 
technological breakthrough scenario is forecast as follow.

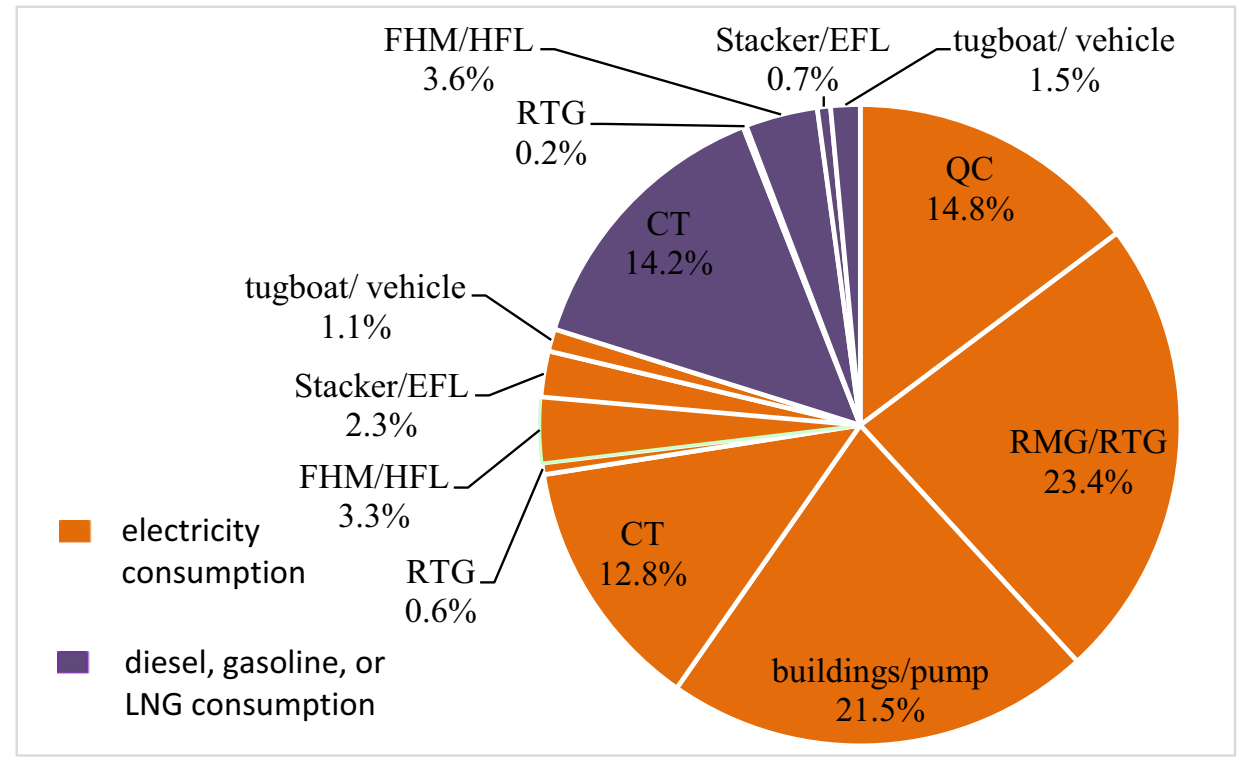

Figure 6. Forecast energy consumption structure in China's container terminal under technological breakthrough scenario

As can be seen from Figure 6 that, in 2030 under the technological breakthrough scenario:

- Consumption of diesel, gasoline and LNG will account for about $20.2 \%$ of the total energy consumption, which is $34.8 \%$ lower than now. In addition, it can be seen from Figure 5 that the consumption of diesel oil, gasoline and LNG of China's container terminals is less than that of electric power. In all of the equipment consuming diesel, gasoline or LNG, container tractor consumes most energy, and energy consumption accounts for about $14.2 \%$.

- The direct carbon emissions of China's container terminals per throughput will be about $72 \%$ lower.

\section{Optimization Path of Energy Consumption Structure of Container Terminal}

Based on the prediction of the improvement of energy structure and carbon emission intensity of container terminal under three scenarios, this paper holds that, in order to accomplish China's carbon emission peak task in 2030 ahead of schedule, the port industry should focus on technological breakthroughs, and government should introduce a series of policies.

5.1. Promote the Application of Clean Energy Technologies for Port Machinery and Vehicles

At present, the main problem that restricts the large-scale application of electric-energy 
transport vehicles and mobile machinery is that energy density and power density of the power battery can't meet the demand of port production. Port production is busy and port machinery and vehicles are used frequently, but the battery last no longer to meet the demand of port production. In addition, the cost of electric machinery and vehicles is higher than that of fuel, so it would place a heavy burden on the container terminal economy if they change so large number of fuel machinery and vehicles. [10-13]

As a clean fuel with high calorific value, hydrogen fuel is considered to be the ultimate solution to the future energy crisis. The application of hydrogen fuel cell is another important direction. Up to now, hydrogen container tractors have been used in Qingdao Port Container Terminal, but it still takes some time for the industrialization of hydrogen fuel cells, and the high price of hydrogen fuel have restricted the universal application. [14]

Therefore, it is necessary to focus on lithium batteries, hydrogen fuel cells and other power cell technologies, and accelerate the research and development of clean energy technologies for port mobile machinery and transport vehicles, so as to achieve breakthroughs in power cell technologies and significant cost reductions, and thus accelerate the process of carbon emission peak at container terminals.

\subsection{Use of High-Efficient, Low-Carbon Fuel Machinery and Vehicles}

Reducing carbon emissions from internal combustion engines should improve the thermal efficiency of internal combustion engines, and use "high-efficient and lowcarbon" internal combustion engines that consume less fuel while producing the same power. With the development of intelligent, lightweight, diversified and other new technologies for internal combustion engines, the application of efficient and intelligent combustion systems for internal combustion engines should be strengthened.

The innovation and research of high compression ratio, active and passive precombustion chamber, thin combustion technology, ignition compression ignition technology, high-efficiency supercharger technology, and deep friction reduction technology should be enhanced to achieve further improvement in the thermal efficiency of internal combustion engines [10-12].

\subsection{Improving the Productivity of Fuel Machinery and Vehicles}

With the development of intelligent, information technology, container terminal can optimize scheduling of machinery and vehicle, and then improve production efficiency. Using technologies such as IoT and intelligent algorithms to initiate real-time positioning of trucks and mobile machinery, and carry out intelligent scheduling, with the aim of reducing no-load operation time of port equipment, and improving equipment load factor, etc. Optimize the driving path of trucks and mobile machinery to improve equipment productivity, thus reducing energy consumption and carbon emissions [15-16].

\section{Conclusion}

In the world transportation system, the role of container transportation presents the characteristics of a new value system and maintains a rapid development trend. Optimizing the energy structure of container terminals and promoting carbon neutralization in container terminals are of great significance to promote the early 
realization of carbon neutralization in the port industry and deal with global climate change. The optimization path of energy structure and the realization of carbon peak and carbon neutralization of China's container terminal will provide global container terminals a template for the transformation and upgrading, and energy conservation and carbon reduction. At present, the port industry is in the historical stage of high-tech development strategy. China's container terminal aims to achieve the carbon peak of container terminal by 2030 , which requires to:

(1) apply new energy technology, and promote the application of clean energy technologies for port machinery and vehicles.

(2) apply intelligent technology to container terminal production, and improving the productivity of fuel machinery and vehicles.

(3) promote the improvement of container terminal Automation and electro gasification production process, and use of high-efficient, low-carbon fuel machinery and vehicles.

\section{References}

[1] X J Wu, Research on the development of low-carbon and green container port in China, Master's thesis, Dalian Maritime University, Dalian, China, 2015.

[2] Q Y Li. Carbon emission status and carbon reduction path analysis of waterway transport in China [J]. Transport Energy Conservation \& Environmental Protection, 2021, 17 (2):1-4 (in Chinese) .

[3] Q Y Wang. 2019 China energy statistics [M]. Beijing: IGDP, 2019 (in Chinese) .

[4] $\mathrm{H}$ L Wang, J K He. Peaking rule of $\mathrm{CO}_{2}$ emissions, energy consumption and transport volume in transportation sector [J]. China Population, Resources and Environment, 2018, 28 (2):59-65 (in Chinese) .

[5] H L Wang. Model simulation of China's Low-carbon transformation mechanism and policy [D]. Beijing: Tsinghua University, 2017 (in Chinese).

[6] D Mccollum, C Yang. Achieving deep reductions in US transport greenhouse gas emissions: scenario analysis and policy implications [J]. Energy Policy, 2009, 37 (12): 5580-5596.

[7] X D Qi, X J Li, B W Zhang. Cost effectiveness analysis on emission reduction of greenhouse gas in China: taking electric vehicle as example [J]. Technology Economics, 2017, 36 (4):72-78 (in Chinese).

[8] B J Tang, X Y Li, B Yu, et al. Sustainable development pathway for intercity passenger transport: A case study of China [J]. Applied Energy, 2019, 254: 113632.

[9] Z Y Yuan, Z Y Li, L P Kang, et al. A review of low-carbon measurements and transition pathway of transport sector in China [J]. Climate Change Research, 2021, 17 (1): 27-35

[10] D Xu. Analysis of advantages and disadvantages of hydrogen energy application in port, Water transportation in China, 2020(11)-133.

[11] Z H Feng, X C Wang, H Y Zhang, et al. Path and policy of green transportation development from low carbon perspective [J]. Transport Research, 2019, 5(4): 37-45.

[12] Z Ahoura, H Shima, F Nicole. High-tech business loca-tion, transportation accessibility, and implications forsustainability: Evaluating the differences between high-tech specializations using empirical evidence from U.S. booming regions [J]. Sustainable Cities and Society: 2019,50: 101648.

[13] W M Wey, J Y Huang. Urban sustainable transportationplanning strategies for livable city's quality of life [J]. Habitat International, 2018, 82: 9-27.

[14] Y Yang, C Wang, W L Liu, et al. Microsimulation of low carbon urban transport policies in beijing [J]. Energy Policy, 2017, 107: 561-572.

[15] H Hao, Y Geng, X Ou. Estimating $\mathrm{CO}_{2}$ emissions from water transportation of freight in China [J]. International Journal of Shipping \& Transport Logs, 2015, 7 (6): 676-694.

[16] K Jiang, X Tian, J Xu. China's green economic transition toward 2049 [R]. Washington DC: Brookings Institution, 2020. 